\title{
Applying Innovative Teaching Methods in a Second Language Classroom
}

\author{
Beena Anil
}

SDNB Vaishnav, College for Women, Chennai, India

E-mail:pbeenanil@gmail.com

Received: March 18, $2017 \quad$ Accepted: May 1, $2017 \quad$ Online Published: June 20, 2017

\begin{abstract}
This article focuses on the level of using creative teaching methodologies in second language classroom as studied by the researcher. A series of qualitative methods such as using newspaper, media, movies, interpreting advertisements, and creating Sandblot can be employed in the classroom in order to develop students' second language learning ability. The article focuses on how teaching methodologies should be modified and used in the classroom appropriately by understanding the learning capacity of students and their learning interest in the classroom.
\end{abstract}

Keywords: teaching methodology, innovation, developing confidence, second language learning

\section{Introduction}

English has become an important language in the world. Teachers from second language learning countries are creating innovative methodologies to teach the language in the classroom effectively. To substantiate the statement, Pollock (2007) stated that teachers now rejoice multiplicity and open the doors of public schools to all children, despite their culture, socio-economic status or ability. As classroom set-ups have been changed, curriculum has been expanded to meet all students' needs and teachers are striving to help their students in their classroom to learn and develop their language learning process. Pollock (2007) believed that in order to be successful teachers, they need to incorporate different learning tools keeping in mind the effective teaching methods that are already in use.

\section{Importance of English}

Acquiring English language has become a predominant factor for a nations' development as well as an individual's development. To improve the communicative skills of the learners, innovative teaching methodologies should be used or introduced to make the learning process interesting. Creativity is a prime factor of any student to develop her/ her lateral thinking in terms of learning a language. An English learning classroom should be created using interesting teaching methodologies to mesmerize and encourage students to learn the second language explicitly and implicitly. Second language acquisition has proved that child and adult learners have innate linguistic knowledge in a developmental sequence (Gilkerson, 2006; Schwartz, 2003; Unsworth, 2005).

\section{Aims}

The research paper focuses on the use of creative teaching methodologies in the second language classroom that was observed by the researcher who has one and half decade of teaching experience as English teacher. Using newspaper, clipping from movies, advertisements, and innovative tasks can be used to develop the learning competency of the learners. Ingrarson (2003) pointed out that there are no short cuts to educational improvement. Hence it is important to use relevant and required teaching methods by evaluating students' level of understanding in learning English as a second language.

\section{Improvement of Qualities in Teaching}

The teacher should possess some of the qualities while teaching his/her students. The teacher's personality, attitude, dexterously handling teaching materials, knack in answering students' questions, and ability to teach by using techniques instill interest among students. Traditional methods cannot be written off from the classroom at any point of time, but including some of the interesting and innovating teaching methodologies will make students to be focused on the learning process. Cognitive development teachings can be done in the class through tasks like Sandblot task, 


\section{International Journal of Research in English Education}

newspaper task, advertisement tasks etc., to develop their problem solving ability and lateral thinking skills, otherwise students' individuality and their learning capacity might not be evaluated by the facilitator. DeKeyser (1998) emphasized that the practice of using tasks would go beyond behavior and include various engaging activities that emphasize form-meaning, mappings for day-today communication.

\section{Innovative Methodologies in Teaching English}

Teaching materials, teaching techniques should be updated to the interest of the second language learners. Innovative methodologies like use of games, role play, reading newspaper, watching TV, referring to dictionary etc., should be used as tools in the classroom. Skill based learning, knowledge based learning are essential for the growth and development of students. Krashen's theory of second language acquisition has influenced the development of integrated institution in the classroom at all levels. Krashen (1981) suggests that second language is the most successfully acquired one when the conditions are similar to those present in first language acquisition: that is, when the focus of instruction is on meaning rather than on form; when language input is at or just above the proficiency of the learner; and when there is sufficient opportunity to engage in meaningful use of that language in a relatively anxiety-free environment. This suggests that the focus of learning second language should improve employability skills of the learners.

\subsection{Acquiring English Language through Teaching and Technology}

Learning English is always a difficult process to most of the second language learners. Innovative ideas, interesting teaching materials, practicing and drilling learners for learning the second language should be done through infotainment ways. Students, especially from rural background, find it very difficult to read, write, and speak English even though they studied English as a second language from class I to class XII. These students do not have enough exposure to develop or correct their English extensively. To such students, teachers' role is predominant and teacher should use innovative teaching to make her students develop the second language learning process gradually. Language can be learnt only through practice. Practical knowledge of learning a language is an experimental approach for second language learners. Such learners should experiment their knowledge by communicating with others confidently. Their errors can be rectified or pruned through this practice. Teachers should develop students' confidence, independence, interest, and aid them to realize that their first language knowledge repository would be helpful to learn the second language confidently.

As Stevick (1980) pointed out that learners could 'take their knowledge of the first few words in the new language and figure out additional words by using that knowledge' (p.42). Learners' self-learning approach and understanding the learning ability in the process of learning second language should be given primary importance in the classroom. Teachers should discover activities and tasks that are filled with edutainment. Introducing various tasks would help learners to understand the use of language in real-life situations by engaging them in doing many activities in the classroom.

In the present age, students' acquisition of a language is measured in terms of their ability to communicate in the language rather than examining their grammatical skills. Many educational institutions have taken an extreme step by including a network of computers and related software, cassette players, and slide projectors as a part of English learning process. English plays an important place in every student's life directly or indirectly. Though, chalk and board method is unbeatable, using technological tools in the process of learning English benefits learners voluminously. No more English is considered as a subject by learners, but it is considered as a language by students, thanks to globalization. Crystal (2004) in the preface to his work, Language and the Internet mentions:

An emphasis, which formerly was on technology, has shifted to be on people and purposes. And as the Internet comes increasingly to be viewed from a social perspective, so the role of language becomes central. Indeed, notwithstanding the remarkable technological achievements and the visual panache of screen presentation, what is immediately obvious when engaging in any of the Internet's functions is its linguistic character. If the Internet is a revolution, therefore, it is likely to be a linguistic revolution (p.viii).

In this vying competitive world, most of the institutions have set up language lab for their students to learn English. At present, multimedia lab is quite attractive and instilling the interest of learning the language. The difference between 


\section{International Journal of Research in English Education}

a normal language lab and a multimedia lab is that the former provides audio equipment through which learners can listen to the tapes, record their voices, and communicate with the teacher, while the latter operates as a multifunction tool through which students can either listen to the tapes, watch videos and different TV channels, access internet or communicate with one another while the teacher can operate technical equipment to group or to pair students, and hold discussions within the class. Bryant (2006) expresses that in this technological era learners require good rapport with other learners through chatting, task performance, and virtual collaborative conversational interaction.

\subsection{Motivation and Self-confidence}

Motivation and self-confidence are personality traits which would help students in acquiring a language successfully. They are helpful to develop oneself on the language acquiring process. Self-confidence is a powerful motivation process in acquiring a language especially a second language. The motivation is of two types: extrinsic and intrinsic motivations. Extrinsic motivation is a goal achievement oriented. A learner learns a language in order to get a job, or to get a degree, this mode of motivation is extrinsic motivation. Motivation and exposure to the language would make learners to learn the language. Teachers should motivate students and provide situation to develop self-confidence among them. Teachers should use tasks in the classroom to develop motivation and positive attitudes for the learners that would be suitable for all sort of learners (Agullo, 2006; Nikolor \& Mihaljevic Djigunovic, 2006).

\section{Activity Based Learning in the Classroom}

Every classroom is an important place to impart knowledge where teachers and students are collaborators. J. Richards (2001) expresses that 'Learners roles in an instructional system are closely linked to the teacher's status and function' (p.28). Teachers should think of new and varied activities to empower students to face many real challenges in their future life. Such activities make students to think and react proactively, innovatively and confidently. Performing the activities in the classroom will make students to have authorship over themselves and develop good rapport with teachers and fellow students. Classroom is a space especially means for learners and 'sensible' talking of students should be encouraged. Breen and Cadlin (1980) describe the learner's role in the following terms:

The role of learner as negotiator interacts with the role of joint negotiator within the group and within the classroom procedures and activities which the group undertakes. The implication for the learner is that he should contribute as much as he gains, and

thereby learn in an interdependent way (p.110)

Learners' autonomy is an appreciable act and teachers should understand their students' strength and weakness in learning English as a language rather than a subject. A few prospects can be identified and implemented for a better learning atmosphere. They are

1. Weekly lesson plan teemed with activities should be explained and presented to the students,

2. Provide time to students to think, understand, and perform activities effectively with their competence level,

3. Teachers should be sincere in delivering their work efficiently, keeping in mind primarily the development of students,

4. Teachers should share interesting facts and relevant information about all prescribed subjects in the classroom,

5. Teachers play a pivotal role in creating and stimulating interest among students to have healthy and contextualized discussion from different angles, and

6. Teachers should think of practical activities that should be filled with humor and creativity (Allwright, 1984).

Allwright (1984) pointed out that everything that happens in the classroom happens through person to person interaction. Students should be prepared to perform practical activities in the classroom by the materials provided by the teacher. Activities can mould students to be a thinker, analyzer, judge, and evaluator and aid them to fit in according to the situation. L2 researchers such as Nation (1997), Day and Bamford (1998), and Krashen (2004) have suggested that a vocabulary gain is available to learners who read widely.

English can be learnt in various creative ways. Creativity helps learners to use language relevantly and instantly. Days are gone where students are being trained on soft skills to make their English communication perfect. In the present scenario, students in semi-urban and sometimes in urban areas are successfully placed in Multinational Companies 


\section{International Journal of Research in English Education}

(MNCs) despite their little English knowledge. Once placed in a company, they develop the language through exposure and observation. As students, they should be exposed to various tasks so that they could learn the style of using the second language interestingly and confidently. Skehan (1996) defines a task as 'an activity in which meaning is primary; there is some sort of relationship to the real world; task completion has some priority; and the assessment of task performance is in terms of task outcome.'

Media helps to kindle the learning interest of learners. The computer tools like internet, audio or video clips help learners to interact or listen to the native speakers; this increases the morale of learners. Using video, audio clippings in the classroom is a stimulus for students to communicate about anything interesting and applications like Whatsapp Facebook have become a common 'syndrome' for youth to view and read anything under the sun. Pronunciation, accent, vocabulary, reading, writing, listening, and speaking skills can be taught using media. Students' creative, analytical and productive skills can be honed by showing colorful pictures, inspiring speeches by great people, and current affairs with trouble shooters. This method helps students to improve their communicative skills. Use of media in the classroom is voluminous and using newspaper, visual advertisements and clippings from movies as tools to teach English is a positive move. Bax (2003) expresses:

Computer Aided Language Learning (CALL) finally becomes invisible, serving the needs of learners and integrated into every teacher's everyday practice. It will require change in attitudes, in approach and practice amongst teachers and learners; it will require fuller integration into administrative procedures and syllabuses (p. 27).

This section discusses a few innovative activity based tasks, their procedures, and objectives.

\subsection{Task One: Newspaper}

Newspaper is an important tool to teach students in the classroom. Reading English newspaper should be developed as a habit among students that will help them to improve their vocabulary and love for the language. Though newspaper's primary purpose is to provide news to public, for students it teaches about the nuances of the language through news. A special component of newspaper is that it can be used and read according to the interest of the readers. Every reader's interest is being fed by different columns like film, sports, cuisine, politics, ecology, and science. Students will get a wide choice of selecting and reading newspaper according to their top interest. Rixon's (2011) investigation showed that an integral part of teaching should be teaching activities.

6.1.1 Procedure of the Task

- Instruct students to bring a sheet or a copy of English newspaper to the classroom,

- Divide the class into small group of three each,

- Instruct students to select a write-up or an article from their respective sheet of newspaper,

- Instruct students to read the selected passage and underline the difficult words,

- Instruct them to type the given passage on MS word on the computer in the lab. Select the difficult words with the help of tool synonyms, which is available on MS word, and instruct students to provide synonym to each difficult word,

- Instruct students to read the modified passage, and

- Instruct each team to describe the piece of passage from the newspaper and later from the computer.

Multiple words help them to enhance their vocabulary and have a wide choice of selecting an equivalent word of their choice. Nation's (1997) research suggests that it takes at least 12 separate reading encounters with a new word in context for learners to learn words that are comprehended to some extent.

6.1.2 Objectives Obtained from the Task

- Vocabulary is enriched,

- Students' computational skill can be improved,

- Improvement of reading skill,

- Improvement of speaking skill, 


\section{International Journal of Research in English Education}

- Improvement of listening skill,

- Improvement of pronunciation, and

- Enhancement of proper use of selective words. Anil (2016) shares that when students start to expand the boundary of learning even outside the classroom is considered to be a healthy learning approach.

\subsection{Task Two: Regional Visual Advertisements}

Advertisements are very colorful and most of them come with stories. Adults enjoy watching advertisements that make them to learn concepts and the language implicitly. Many regional advertisements bring awareness about cleanliness, hygiene, confidence, self-confidence, patience, and education. Such advertisements provide a short message, an important concept, providing scope of expansion and production of language and content that are different from other learning techniques used in the language learning process. Myhill (2006) identified that 'relatively little interaction supports and scaffolds children in their learning' (p. 24).

6.2.1 Procedure of the Task

- Instruct students to download an advertisement from the internet of their choice,

- Divide the class into small group of two each,

- Instruct students to write down the English words used in the regional advertisement,

- Instruct them to write the meaning sentences using each English word used in the advertisement,

- Provide a few minutes to prepare sentences to each team, and

- Instruct each team to play the selected advertisement and the English words along with the sentences to the class. According to Peccei (2000), in first language learning errors are rarely explicitly corrected with the emphasis placed on elaborating or expanding on learners' utterances.

\subsubsection{Objectives Obtained from the Task}

- Students' creativity can be evaluated,

- Students' understanding skills can be developed,

- Vocabulary can be enhanced,

- Observational skill is developed, and

- Good rapport with classmates is developed.

Oller and Eilers (2002) suggested that learners who were taught in both L1 and L2 fared better than those who taught in English only.

\subsection{Task Three: English Visual Advertisements}

Advertisement is a mini movie with an interesting visual concept or theme. Words used in such advertisements are glamorized with style, good pronunciation. Identifying signature lines, headlines, captions, slogans etc., in English advertisements are quite expressive for viewers that help them to learn English instantly. Identity is increasingly recognized as an important variable underpinning for second language learning success (Block, 2007).

\subsubsection{Procedure of the Task}

- Divide the class into small groups of two or three students in each,

- Instruct each team to download an English advertisement of its choice from internet,

- Provide time to understand and explain the advertisement within the team,

- Instruct each team to enact a performance similar to the theme or concept of the chosen advertisement,

- Copy each team's chosen advertisement to the teacher's computer so that she/he can scrutinize and evaluate, and 


\section{International Journal of Research in English Education}

- Before performing, each team should narrate the concept of the advertisement and then enact or narrate the team's self-made advertisement to the classmates. Ellis (1985) justified that teachers should play an active role in helping learners to stretch their resources and to build 'new' utterances types.

\subsubsection{Objectives Obtained from this Task}

- Students computational skill can be developed,

- Creativity can be enhanced,

- Understanding of English language along with visuals can be evaluated,

- Artistic skill can be developed, and

- Construction of English sentences can be scrutinized.

Black (2009) was interested in the ways that the activities enable learners to evolve new forms of L2 identities.

\subsection{Task Four: Clippings from Regional Movies}

Movies are a larger version of visual treat with glamorous ingredients. Youth are attracted towards movies and the star cast. They learn words through movies because of their interest and involvement in watching such movies. Such attitude aids students to register the conceptual meaning of different words. Barrett (2007) stressed that while designing materials a need to bear in mind of the teacher is learners' cognitive and emotional development.

\subsubsection{Procedure of the Task}

- Instruct students to download a scene from a movie from internet or a scene from Facebook or Whatsapp or any other technical application,

- Divide the class into small groups of two or three students in each,

- Instruct each team to observe the selected scene on the computer or the Smartphone provided,

- Provide time for preparation,

- Instruct students to give voice over to each character in the specified scene in English,

- When the scene is screened, screen-voice should be muted so that the team members can dub the scene to the class, and

- Humorous exchanges or sentences can be used.

The use of such situations results in more complex language production by learners and higher-order thinking (Nunan, 1987).

6.4.2 Objectives Obtained from the Task

- Creativity can be developed,

- English speaking skill can be enhanced,

- Good rapport with classmates can be developed,

- Cognitive skill can be evaluated,

- Observational skill can be developed,

- English vocabulary and sentence structures can be developed, and

- Sense of humor can be estimated. Nault (2008) argued that learners need to work with materials that are more relevant of the diverse settings where English is used.

\subsection{Task Five: Sandblot Pictures}

Creative skill of learners can be developed by making the narrative entertaining. Eclectic process of exchanging and sharing ideas by expressing ideas with others in diverse is the essential requirement of the task. Learner can be allowed to narrate the self-made pictures on their own that would unleash their creativity. Kumararadivelu (2011) observed that the development of language learning practice would require teachers' consciousness development of awareness and responsiveness to the content surrounding the learning atmosphere. 


\section{International Journal of Research in English Education}

\subsubsection{Procedure of the Task}

- Divide the class into group of two in each team,

- Instruct students to bring sand and compartmentalize it into different shades using color powder,

- Instruct students to apply liquid glue on a paper in a random way,

- Advise students to apply color sand on the glue applied sheet of paper,

- Each team will get a colorful modern picture made out of sand,

- Instruct all members of the team to narrate the modern picture on their own,

- Provide time for preparation,

- Probably, students narrate the picture as a story or an incident, and

- Narrative skill and speaking skill can be evaluated.

Masuhara (2005) shared the point that the context prompted a sharing of meaning and understanding that will develop to fix the multi-dimensional mental representations in the learners' minds that is important for long term retention.

\subsubsection{Objectives Obtained from the Task}

- Creativity can be developed,

- Narrative skill is enhanced,

- English communicative skill can be developed,

- Story narration in an interesting way will grab the attention of the classmates, and

- Confidence and moral can be developed when the teacher supports students in a positive way. Activities should aim to promote both higher-order skills and lower-order skills (Scrivener, 2007).

\section{Conclusion}

Krashen and Tarrell (1983) are of the view that 'Language acquisition can take place only when people understand messages in the target language' (p. 19). Through understanding the level of students' learning abilities and capabilities, teachers can focus on providing variety of activities to students to develop their language learning skills. Teacher should create a congenial atmosphere in the classroom in which learners would feel comfortable to be a part of the learning process. Teacher should encourage and welcome ideas from the students without any prejudice. Teacher should give enough private space to students to allow them to think critically and develop their lateral thinking for their better future. Using innovative methodologies in teaching English in the classroom will pave a positive way to students to learn the language meaningfully. Students will understand the significance of learning English as a second language without any fear which will help them to equip with the power of confidence and achievement. Teachers should involve wholeheartedly while designing tasks for students as every student in the classroom should be involved and benefited. Teachers should also concentrate on providing effective curriculum development for students with learning-driven nature instead of examination-driven nature scenario.

\section{References}

Allwright, D. (1984). The importance of interaction in classroom language learning. Applied Linguistics, 5(2), 156179. doi: https://doi.org/10.1093/applin/5.2.156

Agullo, G. L. (2006). Overcoming age-relate differences. ELT Journal, 60(4), 365-373. doi: https://doi.org/10.1093/elt/cc1027

Anil, B. (2016). Top-up students second langue talk time through Vlogs. Indonesian Journal of EFL and Linguistics, 1(2), 129-143. doi: http://dx.doi.org/10.21462/ijefll.v1i2.9

Barrett, M. (2007). Children's knowledge, beliefs and feelings about nation and national groups. Hove: Psychology Press.

Bax, S. (2003). CALL: Past, present and future. System, 31(1), 13-28. doi: 10.1016/S0346-251X(02)00071-4 


\section{International Journal of Research in English Education}

Black, R. W. (2009). Online fan fiction, global identities, and imagination. Research in the teaching of English, 43(4), 397-425.

Block, D. (2007). Second language identities. London: Continuum.

Breen, M., \& Candlin, C. (1980). The essentials of a communicative curriculum in language teaching. Applied Linguistics, 1(2), 89-112. doi: https://doi.org/10.1093/applin/I.2.89

Bryant, T. (2006). Using world of warcraft and other MMORPGs to foster a targeted, social, and cooperative approach toward language learning. Available at: htmp// www.academiccommons.org/commons/essay/bryantMMORPGs-for SLA.

Crystal, D. (2004). Language and the Internet. Cambridge: Cambridge University Press.

Day, R. R., \& Bamford, J. (1998). Extensive reading in the second language classroom. Cambridge: Cambridge University Press.

DeKeyser, R. (1998). Beyond focus on form: Cognitive perspectives on learning and practicing second language grammar. In C. Doughty \& J. Williams (Eds.), Focus on Form in Classroom Second Language Acquisition. Cambridge: Cambridge University Press.

Ellis, R. (1985). Teacher-pupil interaction in second language development. In Gass, S. M., \& Madden, C. G. (eds) Input in Second Language Acquisition. Cambridge: Newbury House Publishers, pp. 69-85.

Gilkerson, J. (2006). Acquiring English practice verbs: Age and transfer effects in second language acquisition. Ph.D. Dissertation, University of California at Los Angeles.

Ingvarson, L. (2003). Getting professional development right. Proceedings of 2003 ACER Research Conference. Melbourne: ACER.

Krashen, S. (1981). Second language acquisition and second language learning. Oxford: Oxford University Press.

Krashen, S. (2004). The Power of reading: Insights from the research ( $2^{\text {nd }}$ edn). Portsmouth, NH: Heinemann.

Krashen, S., \& Terrell, T. (1983). The natural approach: Language acquisition in the classroom. Oxford: Pergamon.

Kumaravadivelum, B. (2011). Language teacher education for a global society: A modular model for knowing, analyzing, doing, and seeing. London: Routledge.

Masuhara, H. (2005). Helping learners to achieve multi-dimensional mental representation in L2 reading. Folio: Journal of the Materials Development Association, 9(2/1), 6-9.

Myhill, D. (2006). Talk, talk, talk: Teaching and learning in whole class discourse. Research Papers in Education, 21(1), 19-41. http://dx.doi.org/10.1080/02671520500445425

Nation, I. S. (1997). The language learning benefits of extensive reading. The Language Teacher, 21(5), 13-16.

Naultm, D. (2008). Going global: Rethinking culture teaching in ELT context. Language Culture and Curriculum, 19(3), 314-328. doi: 10.1080/07908310608668770

Nikolor, M., \& Mihaljevic Djigunovic, J. (2006). Recent research on age, second language acquisition and early foreign language learning. Annual Review of Applied Linguistics, 26, 234-260. doi: https://doi.org/10.1017/S0267190506000122

Nunan, D. (1987). Communicative language teaching: Making it work. ELT Journal, 41(2), 136-145. doi: https://doi.org/10.1093/elt/41.2.136

Oller, D. K., \& Eilers, R. E. (eds) (2002). Language and literacy in bilingual children. New York: Multilingual Matters.

Pecceim, J. S. (2000). Child language. Beijing: Foreign Language Teaching and Research Press and Routledge.

Pollock, J. E. (2007). Improve student learning one teacher at a time. Association for Supervision and Curriculum Development. Alexandria, VA. 


\section{International Journal of Research in English Education}

Richards, J., \& Rodgers, T. (2001). The nature of approaches and methods in language teaching. In Approaches and Methods in Language Teaching. United Kingdom: Cambridge University Press.

Rixon, S. (2011). Beyond ABC: Investigating current rationales and systems for the teaching of early reading to young learners of English. Unpublished doctoral thesis, University of Warwick.

Schwartz, B. D. (2003). Child L2 acquisition: Paving the way. In B. Beachley, A. Brown \& F. Conlin (eds.), Proceedings of the $27^{\text {th }}$ Annual Boston University Conference on Language Development. Somerville, MA: Cascadilla Press, pp-26-50. Scrivener, J. (2007). Learning teaching ( $2^{\text {nd }}$ edn). London: Macmillan.

Skehan, P. (1996). A framework for the implementation of task-based instruction. Applied Linguistics, 17(1), 38-62. doi: https://doi.org/10.1093/applin/17.1.38

Stevick, E. (1980). Teaching language: A way and ways. Rowley, Mass: Newbury House.

Unsworth, S. (2005). Child L2, adult L2, child L1: Differences and similarities. A study on the acquisition of direct object scrambling in Dutch. Ph.D. Dissertation, Utrecht University. 